\title{
A vállalatok teljesítményének elemzése Balanced Scorecard alkalmazásával
}

\section{An Analysis of Corporate Performance Using the Balanced Scorecard}

\section{ÖsSZEFogLALÁs}

Az írás elsốsorban a Balanced Scorecard módszer felhasználásával készült tanulmányok összehasonlításán alapul. A szakirodalmi szintézis elsôdleges célja, hogy beszámoljon különbözô közép- és kelet-európai országokban végzett kutatásokról, melyek a Balanced Scorecard teljesítménymérô módszer részvénytársaságoknál való használatával kapcsolatosak, áttekintve az általuk közzétett jelentési gyakorlatok alapján a legfontosabb érdekhordozók szempontjait. Az összehasonlítás elvégzésével jól látható, hogy a Balanced Scorecard módszer kedvezó a külsố felhasználók számára fontos információk, intézkedések és teljesítménymutatók közlésére és elemzésére, a vállalati éves jelentések felhasználásával.
Journal of Economic Literature (JEL) kódok: M12, M21, G34

Kulcsszavak: Balanced Scorecard, nem pénzügyi teljesítménymérés, részvénytársaságok, éves jelentések, érdekelt felek

\section{Summary}

This article is mainly based on a review and comparison of studies using the Balanced Scorecard method. The fundamental aim of the literature synthesis is to report on the research of companies limited by shares in Central and Eastern European countries, conducted using the Balanced Scorecard performance measurement method, based on the published reporting practices of the latter, and taking the considerations of the most important stakeholders into account. The com-

VÁGNer VikTor PhD-hallgató, Debreceni Egyetem (vagner.viktor@outlook.hu). 
parison clearly shows that based on the relevant companies' annual reports, the Balanced Scorecard method is suitable for communicating and analysing information, actions and performance indicators important for external users.

Journal of Economic Literature (JEL) codes: M12, M21, G34

Keywords: Balanced Scorecard, nonfinancial performance measurement, joint-stock companies, annual reports, stakeholders

\section{Bevezetés}

Régóta általánosan elfogadott vélemény a menedzserek körében, hogy a vállalatok teljesítményét különbözô nézôpontokból, a velük kapcsolatba kerüló legfontosabb érdekhordozó felek figyelembevétel érdemes szemügyre venni, prezentálni. A vállalatok által elért eredmények érdekhordozók irányába történô hangsúlyozása egyre fontosabbá vált, ezért a kötelezô érvényú pénzügyi jelentések és beszámolók közzétételén túl használatossá vált a nem pénzügyi információk és intézkedések bemutatása is. A vállalatok pénzügyi és nem pénzügyi intézkedésein alapuló teljesítménymérési módszerek (PMS) elsôsorban a menedzserek, tulajdonosok és más belsố érintettek számára nyújtanak visszaigazolást az elért eredményekrôl, de olyan funkcióval is elláthatók, amelylyel a külsố érdekhordozók számára releváns információk is kommunikálhatóak. Az egyik ilyen teljesítménymérô módszer a Balanced Scorecard, a rendszert alkotó négy nézôpont segítségével lehetôség adódik nemcsak a belsô, hanem a külsố érdekelt felek elvárásaihoz és igényeihez igazodó célok elérésére is.

\section{A Balanced Scorecard Mint TELJESÍTMÉNYMÉRÖ ESZKÖZ}

A szervezeti teljesítmény támogatására számos stratégiaimenedzsment-eszköz és -technika (SMTT) javasolható (költség-haszon elemzés, tevékenységalapú költségszámítás, Balanced Scorecard, vevőjövedelmezôség-számítás stb.), amelyek, a vállalat helyzetének megismerésével és a versenytársakkal való összehasonlításával, hozzájárulnak az ügyfelek elégedettségének javításához és megtartásához, a piaci részesedés és a nyereség növeléséhez (Afonina, 2015:21). Nagy számban születtek tanulmányok, amelyekben többnyire kérdôíves módszerrel készítettek kutatást a stratégiaimenedzsment-eszközök és a nem pénzügyi mérési módszerek használatáról (Todorovic és szerzôtársai 2015-ben Szerbiában, Rajnoha és Lesníková 2016-ban Szlovákiában, Afonina 2015-ben Csehországban. A Kaplan és Norton nevével fémjelzett Balanced Scorecard az egyik legnépszerúbb stratégiai teljesítménymérô eszközzé lépett elô az utóbbi években. A profitorientált vállalatok mellett sikeresen adaptálták közszervezetek, nonprofit szervezetek, valamint állami szervezetek, önkormányzatok is, sôt születtek javaslatok a felsôoktatási intézmények múködési struktúrájának átszervezésére is a módszer üzleti mintájú bevezetésével (Sartorius et al., 2010; Greiling, 2010; Kozma-Kazainé Ónodi, 2014; Gácsi et al., 2015).

A Balanced Scorecard rendszert Kaplan és Norton (1992) eredetileg a teljesítmény mérésére tervezte. A mutatószámrendszer a kor kritikáinak kereszttüzében álló, hagyományos pénzügyi intézkedések teljesítménymérését kiegészítve olyan intézkedéseket is magában foglal, melyek 
az ügyfelek elégedettségére, a belsô folyamatokra, valamint a szervezet innovációs és tanulási tevékenységeire vonatkozó operatív, nem pénzügyi mérésekre vonatkoznak. A pénzügyi információk önmagukban már nem elegendóek a döntések meghozatalához, sokkal pontosabb és megbízhatóbb képet kaphatunk az átfogó teljesítményértékelésben, ha a nem pénzügyi szempontok és intézkedések eredményeit is figyelembe vesszük, így az egyes érdekelt felek elvárásainak is megfelelünk (Low-Siesfeld, 1998). Azok a vállalatok, amelyek csak a pénzügyi intézkedésekre koncentrálnak, már nem képesek fenntartani a versenyelónyüket (Jovetic-Puric, 2016). Habár a vállalat pénzügyi teljesítménye kulcsfontosságú kérdés, a probléma mégis abban gyökerezik, hogy a vállalat teljesítménye az egyes érdekelt felek szemszögébôl különbözó megközelítésekben nyilvánul meg, vagyis kérdéses, hogy megvalósul-e az értékteremtés az összes érintett fél számára (Jáčová-Brabec, 2017). A hagyományos, pénzügyi szemléletû teljesítménymérési rendszerek nem kapcsolódnak az operatív stratégiákhoz, a pénzügyi adatokon alapulva a múltra fókuszálnak, a költségek csökkentésére helyezik a hangsúlyt, és egyéni érdekek valósulnak meg, szemben a stratégiai mérési rendszerekkel, amely viszont az operatív stratégiák érdekében múködik, az ügyfélközpontúság jellemzi, vagyis a jövơre fókuszál; a teljesítmény javítása nagy jelentôséggel bír, az egész szervezet tanulásának biztosításával csoportos ösztönzók hatják át (McNair et al., 1990).

Kaplan és Norton (1992) 12 vállalat egy évtizedes megfigyelésére alapozva megállapította, hogy a vezetốk a pénzügyi és operatív intézkedések kiegyensúlyozott bemutatását szeretnék megvalósítani, nem kizárva, hogy több intézkedéscsomagra támaszkodnak. Elméleti megközelítésból és korábbi kutatási eredményeket figyelembe véve beigazolódott, hogy a különbözô irányítási eszközök és technikák felhasználása segít a vállalatoknak

- reagálni a belsố és külsố versenykörnyezet változásaira,

- a stratégiaimenedzsment-tevékenység strukturálásában,

- a döntéshozatali folyamat támogatásában,

- az ügyfelek igényeinek kielégítésében,

- a pénzügyi teljesítmény javításában,

- a termelési költségek racionalizálásában és az új lehetôségekre való rávilágításában.

Így tehát a különbözố irányítási eszközök és technikák elfogadása és kombinációja javíthatja a pénzügyi és nem pénzügyi intézkedéseket (Afonina, 2015:22).

Kaplan és Norton (1992) az általuk megfigyelt vállalatok alapján arra jutott, hogy a felsố vezetôk olyan mérési módszereket alkalmaztak, melybe a vállalatok jövôképét és prioritásait is bevonták. Megállapították, hogy a vállalatok által kiválasztott teljesítménymutatók igen értékes információkat tartalmaznak a jövốbeli stratégia kialakításához, valamint hogy a vállalatok ezeket a teljesítménymutatókat egy irányítási rendszerbe integrálják. Éppen ezért a Balanced Scorecard jóval több, mint teljesítménymérési rendszer (PMS). Azon túl, hogy alkalmas pénzügyi és nem pénzügyi adatok értékelésére, a stratégiai menedzsment területén is használható vezetési, irányítási rendszerként. A Balanced Scorecardot a vállalatvezetési rendszerek középpontjában kell elképzelni, mellyel nyomon követhetôvé válnak 
a rövid távú pénzügyi eredmények, és a legutóbbi teljesítmény fényében értékelhetô a vállalat stratégiája. A szerzôpáros hangsúlyozza, hogy a Balanced Scorecard koncepcióját az egész vállalat felé kommunikálni kell, hogy a tulajdonosokon át az alkalmazottakig mindenki megértse a hosszú távú stratégiai célokat, sôt az ily módon hozott intézkedések eredményeit a lehetséges befektetôk számára is kommunikálni kell (Kaplan-Norton, 1996).

Elméletileg a Balanced Scorecard négy elkülönült nézôpontjának - pénzügyi teljesítmény, ügyfelek, belsô múködés, innováció és tanulás - összefüggésrendszere lehetôvé teszi, hogy nemcsak a tulajdonosok, részvényesek, hanem az érdekeltek szempontjából is meg lehessen ítélni, hogy milyen teljesítménnyel szolgált számukra a vállalat. Ezt alátámasztja Vinten (2001) „érdekelt felek” elmélete (stakeholder theory), vagyis a vállalatokat az összes érintett fél érdekeit szem előtt tartva érdemes múködtetni. Sternberg szerint egy szervezet érdekeltje lehet minden olyan csoport vagy egyén, amelyek vagy akik befolyásolhatják a szervezetet (Vinten, 2001). A stratégiailag releváns érdekelt felek a részvényesek, ügyfelek vagy alkalmazottak, míg a lehetséges érdekelt felek a potenciális részvényesek, ügyfelek, alkalmazottak; további stratégiai jelentôségú felek lehetnek még a beszállítók vagy a társadalom egésze (Bieker, 2005). Nem szabad figyelmen kívül hagyni a vállalatok érdekköreibe tartozó, akár nagy befolyással bíró versenytársakat sem.

A Balanced Scorecardot az érdekelt felek igényeinek fokozott figyelembevételére tervezték, ugyanis ezt tükrözi az ügyfelek, munkavállalók és a részvényesek érdekeinek kifejezett szemmel tartá- sa, mely viszont csak akkor lehetséges, ha a vállalati stratégiai célok megvalósulnak (Bieker-Waxenberger, 2002).

\section{A Balanced Scorecard és aZ egyes ÉRINTETT FELEK KÖZÖTTI KAPCSOLAT}

A Balanced Scorecard a következó négy alapvetô kérdésre keresi a választ: hogy tekintünk a tulajdonosokra (pénzügyi perspektíva), hogyan látnak minket az ügyfelek (ügyfélperspektíva), miben kell kitûnnünk (belsô perspektíva), tudunk-e még tovább javulni és értéket teremteni (innováció és tanulás perspektívája) (Kaplan-Norton, 1992:72). Minden egyes tevékenységet és intézkedést a perspektívák vonatkozásában a vállalatok jövedelmezôségére gyakorolt hatásuk alapján kell megítélni (Bieker-Waxenberger, 2002). $\mathrm{Az}$ érdekhordozók igényei, követelményei ebbe a négy nézôpontba integrálódnak (Bieker, 2005).

A következókben a Balanced Scorecard és a legfontosabb, stratégiai érdekhordozók közötti kapcsolatot mutatjuk be a releváns szakirodalmak áttekintésével.

\section{$\ddot{U g y f e l e k}$}

Sok olyan vállalat van, amely elsôsorban az ügyfélre összpontosít. Kaplan és Norton (1992) szerint az ügyfelek számára valóban fontos tényezók négy kategóriába sorolhatóak: az idô, a minôség, a teljesítmény és szolgáltatás, valamint a költségek. Annak érdekében, hogy egy vállalat valóban megfeleljen az ügyfelek elvárásainak, külsố méréseken alapulva, az ügyfelektôl gyújtött adatokra támaszkodva érdemes kidolgoznia a saját teljesítménymutatóit. A kiváló teljesítmény mégis a szervezeten 
belüli folyamatokból, a belsô döntésekkel és intézkedésekkel érhetô el. A menedzsereknek a kritikus belsó múveletekre kell összpontosítaniuk, amelyek az ügyfelek igényeinek kielégítésére szolgálnak. A Balanced Scorecard belsố intézkedéseinek olyan üzleti folyamatokból kell származnia, amelyek a legnagyobb hatást gyakorolják a vevôi elégedettségre. Az innováció és tanulás perspektívája szempontjából, amely új termékek gyártásának stabilitását, nem pedig a meglévố termékek gyártásának javítását hirdeti, az új termékek bevezetése és elfogadtatása jelenti az ügyfelek számára a legnagyobb értékteremtést. A hagyományos pénzügyi intézkedések nem javítják az ügyfelek elégedettségét, a minôséget, a ciklusidôt, a munkavállalói motivációt. Habár a pénzügyi teljesítmény operatív cselekvések eredményeiból fakad, de még a jobb múködési, operatív teljesítmény és a pénzügyi siker közötti állítólagos kapcsolat is meglehetôsen gyengének és bizonytalannak nevezhetô. A szerzôpáros ezt egy példával magyarázza, mely szerint egyáltalán nem biztos, hogy a gyártási képességek jelentős javulása nagyobb jövedelmezôséggel fog járni.

\section{Alkalmazottak}

A menedzsereknek a belsố üzleti nézôponton belül olyan intézkedéseket kell kidolgozniuk, amelyek az alkalmazottak viselkedését és hozzáállását befolyásolják az idôt (ciklusidô), minôséget, termelékenységet és költségeket érintő célok elérése érdekében, mellyel hangsúlyozzák a vevői elégedettség növelésének és a belsô üzleti folyamatok folyamatos fejlesztésének fontosságát. A Balanced Scorecard a részvényesek és az ügyfelek számára is jelzi, mit kíván elérni a szervezet, de az al- kalmazottak egyéni teljesítményének a vállalati stratégiával való összehangolásához a Balanced Scorecard használóinak három tevékenységet szükséges folytatni: kommunikáció és oktatás, célok meghatározása és a jutalmak összekapcsolása a teljesítménymutatókkal. A Balanced Scorecard kommunikálása elôsegíti az alkalmazottak hosszú távú stratégia iránti elkötelezettségét, és hozzájárul a vállalat jövooképének megvalósításához (Kaplan-Norton, 1996).

A globalizáció miatt egy vállalat teljesítménye egyre inkább függ a humán tôke ismereteitôl és készségeitôl. Ez az egyetlen olyan termelési tényezó, amely képes gyorsan és aktívan reagálni a környezeti változásokra. A humán tóke (a vállalat alkalmazottainak képessége, tehetsége és ismerete) a tanulás és innováció perspektívában azonosítható immateriális kategória (az információs tôke és a szervezeti tôke mellett), amely nélkülözhetetlen bármely stratégia megvalósításához (Kaplan-Norton, 2004). A munkavállalók tudása és képzettsége jelenleg az üzleti életben maradás egyik legfontosabb tényezôje. A pénzügyi és reáleszközökkel ellentétben az immateriális javak a versenytársak számára nehezen utánozhatók, ami a versenyelôny megórzését segítheti. Ha a vezetốk az immateriális javak értékét helyesen tudják megbecsülni, akkor sokkal könnyebben és pontosabban mérhetik vállalatuk versenyképességét (Jáčová-Brabec, 2018).

\section{Részvényesek}

A Balanced Scorecard pénzügyi perspektívája tipikusan a jövedelmezôséggel, a növekedéssel és a részvényesi értékkel kapcsolatos. A pénzügyi elemzésekhez a szerzôpáros a részvényesi értékelemzést 
javasolja (SVA), amellyel egy elôrejelzô értéket kapunk a jövóbeni pénzáramok becsült értékének jelenértékre diszkontálásával. Az innováció és tanulás perspektívája szempontjából az új piacokra történó behatolás növelheti a bevételeket, ezáltal növelve a részvényesi értéket (KaplanNorton, 1992).

A szerzôpáros bátorítja a felsố vezetôket arra, hogy az intézkedések által elért kecsegtetô eredményekrốl a lehetséges befektetôket is tájékoztassák, mégpedig úgy, hogy éves jelentéseiket stratégiai intézkedésekkel is egészítsék ki, de olyan információkat is közzétehetnek, melyek például magukban foglalják a piaci részesedés mértékét, az ügyfelek elégedettségét, a munkavállalói kompetenciákat, a bevezetett technológiákat. Így elméletileg a Balanced Scorecard a stratégia külsố kommunikálására és értékelésére is felhasználható (Kaplan-Norton, 1996).

A Balanced Scorecard egyensúlyt teremt az ügyfeleknek és a részvényeseknek szóló külsố intézkedések, valamint az üzleti folyamatok, az innováció, a tanulás és a növekedés belsô intézkedései között (Chavan, 2009).

Kaplan és Norton munkáira támaszkodva az 1. táblázat összefoglalja az érdekhordozók által értékelt szempontokat a Balanced Scorecard alkalmazásával.

\section{A Balanced Scorecard alkalmazása RÉSZVÉNYTÁRSASÁGOK ESETÉBEN HÁROM ORSZÁG NÉZŐPONTJÁBÓL}

Rengeteg kutatómunka vizsgálja a Balanced Scorecard teljesítménymérô funkcióját, ugyanakkor számos különbség van a kutatások módjában és az elemzett mintaszámokban. A következố tanulmányok különbözố országokat vizsgálnak, melyeknél eltérô mintaszámban történtek az elemzések; ami viszont közös mindegyik esetben, hogy részvénytársaságok esetében folytatták a vizsgálatokat, fốként a vállalatok által nyilvánosságra hozott riportok, jelentések alapján tanulmányozták a teljesítménymutatók közzétételi gyakorlatát.

\section{1. táblázat: Teljesítménymérés Balanced Scorecard módszerrel az egyes érdekhordozók által} értékelt szempontok szerint

\begin{tabular}{|c|c|c|c|c|}
\hline & $\begin{array}{c}\text { Ügyfelek } \\
\text { nézőpontja }\end{array}$ & $\begin{array}{c}\text { Üzleti folyamatok } \\
\text { nézôpontja }\end{array}$ & $\begin{array}{l}\text { Tanulás és inno- } \\
\text { váció nézốpontja }\end{array}$ & $\begin{array}{l}\text { Pénzügyi } \\
\text { nézópont }\end{array}$ \\
\hline Ügyfelek & $\begin{array}{l}\text { Idô, minôség, } \\
\text { teljesítmény } \\
\text { és szolgáltatás, } \\
\text { költségek }\end{array}$ & - & - & - \\
\hline Alkalmazottak & - & $\begin{array}{c}\text { Hozzásegíteni a } \\
\text { vállalatot a célok } \\
\text { eléréséhez és a } \\
\text { jövốkép megvalósí- } \\
\text { tásához }\end{array}$ & $\begin{array}{l}\text { Folyamatos } \\
\text { tanulási, fejló- } \\
\text { dési lehetôség, } \\
\text { elégedettség }\end{array}$ & $\begin{array}{l}\text { Jutalmak ösz- } \\
\text { szekapcsolása a } \\
\text { teljesítménnyel }\end{array}$ \\
\hline Tulajdonosok & - & - & - & $\begin{array}{c}\text { Jövedelmezôség, } \\
\text { növekedés, rész- } \\
\text { vényesi érték }\end{array}$ \\
\hline
\end{tabular}

Forrás: Saját szerkesztés Kaplan-Norton, 1992; 1996; 2004 alapján 
Osztrák eset

Mühlbacher és társai (2016) azt vizsgálták, hogy az osztrák értéktôzsdén jegyzett vállalatok a stratégiai teljesítményüket illetôen milyen információkat hoznak nyilvánosságra az üzleti jelentésükben. Ehhez 20 vállalat éves jelentését vizsgálták meg, két egymástól távol esô idôpontban, 2002-ben és 2012-ben. Dokumentum- és tartalomelemzéses vizsgálattal állapították meg, milyen változások, trendek figyelhetôk meg a tôzsdei vállalatok információközlésében, melyet a Balanced Scorecard négy perspektívája közül a pénzügyi nézópontot leszámítva három szempontból - ügyfelek nézôpontja, belsố nézôpont, innováció és tanulás nézópontja - csoportosítottak. A kutatás célja annak megállapítása volt, hogy a nem pénzügyi teljesítménymutatók milyen mértékben jelennek meg az éves jelentésekben. Feltételezték, hogy a nem pénzügyi intézkedések nyilvánosságra hozatalának erôsítenie kell a munkavállalók hosszú távú stratégia iránti elkötelezettségét. Az éves jelentések elemzésével megállapították, hogy a nem pénzügyi intézkedések óriási növekedést mutattak 2002-rôl 2012-re, ami kizárólag az innovációs és a tanulási nézôpontok megnövekedett közzétételi tevékenységéből ered. A közzétett nem pénzügyi intézkedések száma 44\%-kal nôtt 2012-re (a 2002-es 153 intézkedés 2012-ben 221-re nótt, melyből az innováció és a tanulás perspektívája a 2002-es 73 intézkedésrôl 2012-re 151 intézkedésre nôtt), ugyanakkor az ügyfél és a belsô nézőpontok jelentôsége csökkent. Az ügyfélszemlélet 17\%-kal (12 intézkedésrôl 10-re), a belsố perspektíva pedig 12\%-kal csökkent, a 2002-es 68 intézkedésrôl 2012-re 60-ra. Amíg 2002-ben a „növekedés” intézkedés egyértelmúen a leggyakoribb közzétett intézkedés volt, melyet „munkavállalói képzés” és a „K + F” követett, addig 2012-ben a legtöbbször közzétett intézkedés a „munkavállalói sokféleség” volt, melyet a „környezeti fejlesztések" követtek. A százalékos növekedési ütem legmagasabb változása a „szociális fejlesztések” intézkedés, a „munkavállalói sokféleség” és a „környezetvédelmi fejlesztések" mellett következett be. Következésképp megállapították, hogy az innovációs és tanulási perspektíván belül a „munkavállalói sokféleség”, a „környezeti fejlesztések”, a „K + F” és a „munkavállalói képzés” intézkedések óriási növekedésének lehetséges magyarázataként az EU 2003-as korszerúsítési irányelve szolgál, bár a jogi meghatározás nagyon homályos. További eredményeik, mely szerint a vállalatok csökkentették a belsô és az ügyfélszempontú jelentéstételi tevékenységüket, arra utal, hogy a vállalatok óvatosabbak voltak az ilyen típusú közzétételeket illetôen, különösen a belsố folyamatok esetében. Az éves jelentésekben a belsố folyamatok elhanyagolása az alkalmazottak alacsonyabb elkötelezettségéhez vezet, mely érzékenyen érinti a vállalat hosszú távú stratégiáját, így végsố soron a versenyelőnyök elvesztéséhez vezet.

\section{Szerbiai eset}

Duric és munkatársai (2010) egy összetett szervezeti felépítésú részvénytársaság ISO 9001: 2008 szabványokon és TQM-elveken alapuló minôségirányítási rendszere kialakítását vizsgálták Balanced Scorecard módszer alkalmazásával, a vállalat különbözố riportjaira, jelentéseire és külsố szemlélóként saját megfigyeléseikre 
támaszkodva. A részvénytársaság teljesítménymérését a Balanced Scorecard egyik nézôpontja, a belsố folyamatok szemszögéból alkalmazták. A mérés a Balanced Scorecard koncepciójának megfeleló kulcsfontosságú teljesítménymutatókon (KPI) keresztül valósult meg, melyeket az egyes folyamatparaméterek elemzésével határoztak meg. Négy folyamat (gyártás, gépesítés, értékesítés és karbantartás) elemzése egy hónapos idôtartamot vett igénybe. A teljesítménymutatók mérési eredményeivel (82\%, 68\%, 74\%, 83\%) az elért célok százalékos arányát fejezték ki az elóbb ismertetett folyamatok esetében. Megállapították, hogy a folyamatok végrehajtói az eredeti döntések felülvizsgálatával és javításával pozitívan befolyásolhatják az üzleti folyamatok továbbfejlesztését, következésképpen a Balanced Scorecard alkalmazása segít a cégnek a tanulásban és a minôség folyamatos javulásában. Ezáltal érhetô el a vásárlók, a fogyasztók és más érdekelt felek nagyobb megelégedése a termékek, szolgáltatások, illetve a vállalat üzleti rendszerével kapcsolatban.

\section{Lengyel eset}

A Kabalski (2010) által készített lengyelországi felmérésnek több célja is volt. Elsôsorban az, hogy javaslatot tegyen a vállalatoknak a külsố érintettjei számára a teljesítményeikről rendelkezésre bocsátott információk körére és struktúrájára vonatkozóan, melyet az IASB (Nemzetközi Számviteli Standardok) és az ASB (UK Accounting Standards Board) irányelvei szerint állított össze. Másodsorban, hogy megállapítsa, vajon a legnagyobb lengyel tôzsdén jegyzett társaságok teljes körú és kiegyensúlyozott informáci- ót szolgáltatnak-e a teljesítményeikrôl; végül kísérletet tenni az IASB és az ASB irányelveinek, valamint a Varsói Értéktôzsdén (WSE) felsorolt 20 legnagyobb cég által közzétett jelentések értékelésének felhasználásával, a legalkalmasabb jelentés-, információforma bemutatására szolgáló modell kialakítására. A kutatás során arra a következtetésre jutott, hogy a nemzetközi irányelvekkel összhangban a teljesítményrôl szóló jelentéseknek a vállalat múködésének valamennyi lényeges aspektusát, valamint az összes érintett érdekelt fél nézópontját figyelembe kell venni. A vállalat sokoldalú teljesítményének prezentálására egy olyan logikus szabványszerkezetet állított fel, amely a Balanced Scorecard modelljét tükrözi vissza. A Balanced Scorecard módszert a jelentésben szerepló információk szisztematikus bemutatásaként állítja példának, melyben a célokat, a teljesítményt és a tevékenységeket logikailag egymáshoz kell kötni, figyelembe véve a hierarchiát és az ok-okozati viszonyokat. Az eredmények bemutatása történhet üzleti célú (gazdasági) és nem üzleti célú (társadalmi, környezeti) tevékenységenként is. Így a pénzügyi kimutatások felhasználói könynyebben különbséget tesznek az elsôdleges és a másodlagos célok között.

A tôzsdei cégek által közzétett információk vizsgálatára 2009-ben került sor. Az elemzés az alábbi kérdések megválaszolására törekedett: a vállalatok különbözô szempontból tesznek-e jelentést teljesítményükrôl, és létezik-e olyan vállalat, amelynek jelentése modellértékú lehet a vállalat sokoldalú teljesítményeirôl szóló információk bemutatására? A kutatás rávilágított arra, hogy a húsz vállalat egyike sem nyújt sokoldalú jelentést teljesítményeirôl. Bizonyos vállalatok csupán a 


\section{Tudományos múhely}

kötelezô pénzügyi beszámolókat teszik közzé, ellenben akad két említésre méltó vállalat, melyek a gazdasági teljesítmény mellett a társadalmi (munkavállalók, ügyfelek, közösség) és a környezetvédelmi területen is jelentést tesznek teljesítményükrôl. Ugyanakkor a szerzố említést tesz arról, elképzelhetônek tartja, hogy az általa a Balanced Scorecardra épített modell szerint végzi néhány cég a teljesítménye mérését. Mégis a jelentések korlátozottnak, így elégtelennek tekinthetóek ahhoz, hogy mintaként szolgáljanak. A szerzó azt javasolja a Varsói Tốzsde vállalatainak, hogy teljes körú tájékoztatást nyújtsanak teljesítményükrôl az IASB és az ASB ajánlásaival összhangban, így az érdekelt feleknek jelentôsen megkönnyítik a vállalatokkal kapcsolatos, saját maguk által végzett értékeléseket.
Az itt ismertetett közép- és kelet-európai országokban végzett kutatások eredményeit hasonlítja össze a 2. táblázat.

A Balanced Scorecard eltérô elemzési szempontok szerinti alkalmazását az egyes országok kutatói által a 2. számú táblázatban szemléltetve, röviden, a következố megközelítésben lehet összefoglalni.

$\mathrm{Az}$ osztrákok esetében tartalomelemzési módszer valósult meg a tốzsdei vállalatok információközlésében, melyet a Balanced Scorecard négy perspektívája közül, a pénzügyi nézópontot leszámítva, három szempont - ügyfelek nézôpontja, belsố nézốpont, innováció és tanulás nézôpontja - szerint csoportosítottak. A legtöbb intézkedés az alkalmazottak érdekeit szolgálja, amely a munkavállalók stratégia iránti elkötelezettségét képviseli. Ugyan-

\section{2. táblázat: Balanced Scorecard elemzési szempontok és a kapott eredmények nemzetenkénti}

összehasonlítása

\begin{tabular}{|c|c|c|c|}
\hline & Nézőpont & $\begin{array}{c}\text { Fóbb intézkedések, } \\
\text { mutatók }\end{array}$ & Érdekelt fél \\
\hline \multirow[t]{3}{*}{ Ausztria } & $\begin{array}{c}\text { Tanulás és innováció } \\
\text { nézôpontja }\end{array}$ & $\begin{array}{l}\text { Munkavállalói sokféleség, } \\
\text { termelékenység, képzés; } \\
\text { balesetek; szociális fejlesz- } \\
\text { tések; környezeti fejleszté- } \\
\text { sek; K+F }\end{array}$ & $\begin{array}{c}\text { Alkalmazottak, részvé- } \\
\text { nyesek }\end{array}$ \\
\hline & $\begin{array}{l}\text { Belsô folyamatok nézô- } \\
\text { pontja }\end{array}$ & $\begin{array}{c}\text { Növekedés; termelékeny- } \\
\text { ség }\end{array}$ & Részvényesek \\
\hline & Ügyfelek nézôpontja & Vásárlási sorrend & Ügyfelek \\
\hline Szerbia & $\begin{array}{l}\text { Belsô folyamatok nézô- } \\
\text { pontja }\end{array}$ & $\begin{array}{l}\text { Gyártás, gépesítés, értéke- } \\
\text { sítés, karbantartás teljesít- } \\
\text { ménymutatói }\end{array}$ & $\begin{array}{c}\text { Alkalmazottak, részvé- } \\
\text { nyesek }\end{array}$ \\
\hline \multirow[t]{2}{*}{$\begin{array}{l}\text { Lengyel- } \\
\text { ország }\end{array}$} & $\begin{array}{l}\text { Pénzügyi, ügyfél-, belsố } \\
\text { folyamatok, tanulás és } \\
\text { innováció nézôpontja }\end{array}$ & Üzleti célú & $\begin{array}{c}\text { Tulajdonosok, ügyfelek, } \\
\text { alkalmazottak, beszállí- } \\
\text { tók, közösség, pénzügyi } \\
\text { támogatók }\end{array}$ \\
\hline & - & $\begin{array}{l}\text { Nem üzleti célú (társadal- } \\
\text { mi, környezeti célú) }\end{array}$ & Ügyfelek, közösség \\
\hline
\end{tabular}

Forrás: Saját szerkesztés 


\section{Tudományos múhely}

akkor a részvényeseknek is érdekében állnak a fejlesztések, a fejlődés, ha ez az árbevétel növekedésével párosul. Az ügyfeleket szintén érdekli, hogy kik vásárolnak az adott cégtól.

Szerbiában egy adott részvénytársaság esettanulmányában a Balanced Scorecardot a belsố folyamatok nézôpontjából alkalmazták. Kulcsfontosságú teljesítménymutatókat képeztek a gyártás, gépesítés, értékesítés és karbantartás területeken a vállalat különbözô riportjaira, jelentéseire és saját megfigyeléseire támaszkodva. Az ilyen típusú elemzések a részvényesek megelégedésére szolgálnak, de az eredmények az alkalmazottak számára is fontosak, ugyanis függhet tóle a javadalmazásuk.

Lengyelországban húsz, tôzsdén jegyzett részvénytársaság által közzétett beszámolókon, riportokon végeztek tartalomelemzést. Ebból a célból egy elméleti modellt állítottak fel a Balanced Scorecardra alapozva, mely szerint a vállalatok teljesítményét 2 fó szempont szerint kell bemutatni: az üzleti célú és a nem üzleti célú teljesítménymutatók szerinti bontásban. Ennek célja, hogy a kimutatások felhasználói könnyebben különbséget tehessenek az elsôdleges és a másodlagos célok között. Az üzleti célokhoz tartoznak a pénzügyi, ügyfél-, belsố folyamatok és a tanulás-innováció nézôpont, amelyeket a különbözô érdekelt felek szerint lehet osztályozni.

A nem üzleti célú tevékenységeket felosztották társadalmi és környezeti célok szerint, és mint másodlagos tevékenységek a munkavállalók, ügyfelek és a közösség érdekeit szolgálják. A vállalatok által közzétett információk elégtelennek minôsültek az érdekhordozói elvárásokra nézve, habár a modellnek volna relevanciája megfelelô környezetben tesztelve.

\section{KONKLÚZIÓ}

Napjainkban a vállalatok által érdekelt felek elvárásainak és igényeinek való információs megfelelés egyre inkább elôtérbe kerül. Ez a koncepció azt eredményezte, hogy a vállalatok hagyományos pénzügyi és nem pénzügyi mérési módszerekkel prezentált kimutatásokat, jelentéseket tesznek közzé a nyilvánosság számára. Az egyes közép- és kelet-európai országokban végzett kutatások eredményeit összehasonlítva megfigyelhetjük, hogy a Balanced Scorecardot a vállalatok teljesítményének mérésére külsô forrásokból hozzáférhetô, nem pénzügyi dokumentumok információtartalmának feldolgozására lehet használni. A Balanced Scorecard nemcsak mint a vállalat belsố teljesítménymérési rendszereként, illetve vezetési, irányítási eszközeként funkcionálhat, hanem mint elemzési módszer is múködik, a már közzétett információk, intézkedések eredményeire támaszkodva. A külföldi tanulmányok tanúsága szerint a Balanced Scorecard kedvezóen használható múködési, azaz nem pénzügyi tartalmú dokumentumok információs tartalmának elemzéséhez. A vállalatok által prezentált kimutatásokat, éves jelentéseket, stratégiai terveket a Balanced Scorecard négy nézôpontja szerinti felbontásával külön-külön, de átfogóan lehet értékelni akár a külsố érdekeltek, elemzôk által is, így megalapozottabb döntést hozni az adott vállalat teljesítményérôl. A különbözô országokban végzett kutatások eredményei igazolják, hogy a Balanced Scorecard elemzési eszközként való használata számos érdekhordó információhoz való hozzájutását támogatja. Az irodalmi szintézis erôsíti azt a megállapítást, mely szerint a Balanced Scorecard 
alkalmas a hagyományos pénzügyi-, vagyoni- és jövedelmihelyzet-vizsgálatokat kiegészítve az operatív eredmények elemzésére is. A módszer áthidalja a múltorientált pénzügyi adatok és a hosszú távú múködési, stratégiai információk közti szakadékot (Gácsi et al., 2015).

A külföldi tanulmányok között láttunk példát, hogy a négy nézôpont kibôvítésével igény van további perspektívák (pl. környezeti, társadalmi) alapján való döntéshozásra, mely mutatja a módszer rugalmasságát. Mindezt alátámasztani látszik egy korábbi feltételezés, hogy a Balanced Scorecard alkalmazása javasolt lenne a vállalkozások társadalmi, szociális teljesítményének megítéléséhez, méréséhez (Chatterji-Levine, 2006). Az elemzések elvégzéséhez azonban olyan dokumentációkra van szükség, amelyek nem kizárólag a pénzügyi kimutatásokból állnak. Ez függ a különbözô országok jogszabályi környezetétôl, a közzétételre kötelezett dokumentumok típusától. Érdemes lenne, a külföldi kutatómunkák mintájára, hazánkban is elvégezni hasonló vizsgálatokat a hazai vállalatok információjelentési minôségének, tartalmának szemrevételezésével, ezt követôen a Balanced Scorecard használatával az érdekhordozók szemszögébôl elemezni a közzétett pénzügyi és nem pénzügyi információkat.

\section{FELHASZNÁLT IRODALOM}

Afonina, Anna (2015): Strategic Management Tools and Techniques and Organizational Performance: Findings from the Czech Republic. Journal of Competitiveness, Vol. 7, No. 3, 19-36, https://doi.org/10.7441/joc.2015.03.02.

Bieker, Thomas (2005): Sustainability Management with the Balanced Scorecard. In Oehme, Ines - Seebacher, Ulrike (ed.): Corporate Susta- inability: Theoretical Perspectives and Practical Approaches. Technik- und Wissenschaftsforschung, Vol. 51, 121-146.

Bieker, Thomas - Waxenberger, Bernhard (2002): Sustainability Balanced Scorecard and Business Ethics. Developing a Balanced Scorecard for Integrity Management. Contribution to the 10th International Conference of the Greening of Industry Network, Göteborg/Sweden.

Chatterji, Aaron - Levine, David (2006): Breaking Down the Wall of Codes: Evaluating Non-Financial Performance Measurement. California Management Review, Vol. 48, No. 2, 29-51, https://doi.org/10.2307/41166337.

Chavan, Meena (2009): The Balanced Scorecard: A New Challenge. Journal of Management Development, Vol. 28, No. 5, 393-406, https://doi. org/10.1108/02621710910955930.

Duric, Željko - Maksimovic, Rado - Adamovic, Živoslav (2010): Key Performance Indicators in a Joint-Stock Company. African Journal of Business Management, Vol. 4, No. 6, 890-902

Gácsi, Roland - Zéman, Zoltán - Szabó, Zoltán László (2015): Balanced Scorecard in Higher Education. „Mérleg és Kihívások.” IX. Nemzetközi Tudományos Konferencia. Miskolci Egyetem Gazdaságtudományi Kar, 809-813.

Greiling, Dorothea (2010): Balanced Scorecard Implementation in German Non-Profit Organisations. International Journal of Productivity and Performance Management, Vol. 59, No. 6, 534-554, https://doi.org/10.1108/17410401011063939.

Jáčová, Helena - Brabec, Zdeněk (2017): The Evaluation of company performance in the Czech Republic. 4th International Multidisciplinary Scientific Conference on Social Sciences \& Arts SGEM 2017, https://doi.org/10.5593/ sgemsocial2017/hb11/s03.095.

Jáčová, Helena - Brabec, Zdeněk (2018): The Usage of the Balanced Scorecard Concept by Czech Companies. 5th International Multidisciplinary Scientific Conference on Social Sciences E A Arts SGEM 2018, https:/ / doi.org/10.5593/ sgemsocial2018/1.3/s03.054.

Jovetić, Slavica - Puric, Jelena (2016) Comparative Analysis of Financial and Non-Financial Performance Elements of Joint-Stock Companies. Ekonomika, Vol. 62, No. 3, 93-110, https: //doi.org/10.5937/ekonomika1603093j.

Kabalski, Przemysław (2010): Integrated Information about the Multifaceted Performance of 


\section{Tudományos múhely}

the Entity. Comparative Economic Research, Vol. 13, No. 3, 73-92, https://doi.org/10.2478/ v10103-009-0039-y.

Kaplan, Robert S. - Norton, David P. (1992): The Balanced Scorecard - Measures That Drive Performance. Harvard Business Review, January-February, 71-79.

Kaplan, Robert S. - Norton, David P. (1996): Using the Balanced Scorecard as a strategic management system. Harvard Business Review, January-February, 75-85.

Kaplan, Robert S. - Norton, David P. (2004): Measuring the Strategic Readiness of Intangible Assets. Harvard Business Review, February 1, 52-63.

Kozma, Miklós - Kazainé Ónodi, Annamária (2014): Measuring Business Performance in Sports. How the Balanced Scorecard Approach Can Help Sports Organisations in Operating Along Strategic Objectives. Közgazdász Fórum, Vol. 17, No. 118, 17-40.

Low, Jonathan - Siesfeld, Tony (1998): Measures That Matter: Non-Financial Performance. Strategy and Leadership, Vol. 26, No. 2, 24-38, https://doi.org/10.1108/eb054615.

McNair, Carol J. - Lynch, Richard L. - Cross, Kelvin F. (1990): Do Financial and Nonfinancial Performance Measures Have to Agree? Management Accounting, Vol. 72, No. 5, 28-36.
Mühlbacher, Jürgen - Siebenaler, Tom - Würflingsdobler, Ulrike (2016): The Rise of Non-financial Performance Measures in Annual Reports. An Analysis of ATX-listed Companies. Trends Economics And Management, Vol. 10, No. 25, 9-21, http://dx.doi.org/10.13164/trends.2016.25.9.

Rajnoha, Rastislav - Lesníková, Petra (2016): Strategic Performance Management System and Corporate Sustainability Concept - Specific Parametres in Slovak Enterprises. Journal of Competitiveness, Vol. 8, No. 3, 107-124, https: //doi.org/10.7441/joc.2016.03.07.

Sartorius, Kurt - Trollip, N. - Eitzen, C. (2010): Performance Measurement Frameworks in a State Controlled Research Organization: Can the Balanced Scorecard (BSC) be Modified. South African Journal of Business Management, Vol. 41, No. 2, 15-27, https://doi.org/10.4102/ sajbm.v41i2.518.

Todorovic, Miroslav - Kalicanin, Djordje - Nojkovic, Aleksandra (2015): Practices of Performance Measurement in Companies in the Republic of Serbia. Ekonomski horizonti, Vol. 17, No. 1, 45-59, https://doi.org/10.5937/ ekonhor1501045t.

Vinten, Gerald (2001): Shareholder Versus Stakeholder - is There a Governance Dilemma? Corporate Governance, Vol. 9, No. 1, 36-47, https: //doi.org/10.1111/1467-8683.00224. 